\title{
Rural elderly women: The sweat of their bodies and the work of his hands. The paradigms of the Greek polis still present in the current days
}

\author{
Alcione Tavora Kullok \\ Group Human Rights Health Helena Besserman, Foundation Oswald Cruz (Fiocruz), Rio de Janeiro, Brazil; alcionetk@gmail.com
}

Received 27 November 2013; revised 26 December 2013; accepted 3 January 2014

Copyright (C) 2014 Alcione Tavora Kullok. This is an open access article distributed under the Creative Commons Attribution License, which permits unrestricted use, distribution, and reproduction in any medium, provided the original work is properly cited. In accordance of the Creative Commons Attribution License all Copyrights (C) 2014 are reserved for SCIRP and the owner of the intellectual property Alcione Tavora Kullok. All Copyright (C) 2014 are guarded by law and by SCIRP as a guardian.

\section{ABSTRACT}

Background: In Brazil between 1960 and 1990 there established the hegemony of young people between 15 and 24 years old, a phenomenon known worldwide as "youth wave". Forty years later, with continued declining levels of fertility and mortality, in the first decade of this century, the young country came to bear white hair with the continued growth of the aging rate. Official census data show the growth of the elderly population, above sixty years, predominantly female, and population growth increasingly urbanized $[1,2]$. This article reports the findings from a recent study of elderly women, in the contexts of "rurality". Objectives: The aim of this study was to analyze the social construction of gender division of work and retirement of older rural women. Comprehending through historically dialectical materialism, the process of exclusion of rural elderly women, some public policies and programs aimed at elderly populace. Ethnographic Method: fieldwork and interviews (one-to-one and in groups), field notes, participant observation, photography, and archival review. Sample: 27 women aged between 68 to 92 years. Findings: Only four receive retirement as peasant, three owners of land and a former employee; the other receive her husband's pension or are included in the Provision of Continued Benefit (PBC). Conclusion: Non-receipt of retirement for these women, as citizen's peasant, it is a violation of her rights recognized under the Federal Constitution of 1988, and reveals how the Aristotelian paradigm persists in their activities: That sweat of her bodies and the work of her hands, it is not considered as work; it is labor.

\section{KEYWORDS}

Critical Ethnography; Older Women; Rural;
Retirement

\section{INTRODUCTION}

Aging is a universal process, and the growth of the elderly population has caught the attention of different sectors of society, socioeconomic repercussions on individual and collective levels. In Brazil, where the census data show an increasing urbanization of the country and a component of growing older women compared to men, this study aimed to address the aging processes of women in two areas of discussion: the aging of the gender perspective and the rural condition.

The study does not claim to produce a totalizing cultural analysis, but to know and record the stories of these older people, in a rural context. Often, they were overlooked by society and the government. The methodology was ethnography, i.e. I live and record the facts of daily life and its meanings through the reinterpretation of 27 elderly aged above sixty years to 92 years.

Through participant observation, interviews, focus groups of "tales", could become aware that, although it seems a trend in today's society of homogenizing geographical spaces, and des-characterizing their natural references, and (re)characterizing them with production and economic references local cultures remain.

Beginning this theme and adding reflecting words to sentences of Simone de Beauvoir: "nobody is born a woman, becomes woman" [3]; and Chauí [4] "nobody is born adult or old, but always child becomes an adult and old". I will say that nobody is born worker, nor rural. 
Therefore being rural worker is not ontological to woman, but, is a position taken in the world, from the place where the person is located. The biological process of ageing as life cycle is an inevitable phase, heterogeneous, accompanied by psycho-socio-cultural-historical changes, intra and interrelated of the "old" subject. According to Birren and Schroots [5], these dimensions are dynamically included in a continuous process of human interaction. The universal of the behaviors about aging does not prevent from happening numerous old ages in view of the different ways of living, symbolize and represent the aging in each specific society. Research on a group of rural women makes it possible to observe the specificity of aging people in the field, in a historical situation of transformations and emptying of the peasant life. At the same time, I will show, after an apparent homogeneity, that there are differentiations and singularities.

To discuss women and inequalities, it is necessary to address the gender category. Most recently feminists begun to use "gender" as a way of referring to the social organization of the relationship between the sexes [6]. Its use explicitly rejects biological explanations, such as those that find a common denominator for diverse forms of female subordination in the facts that women have the capacity to give birth and men have greater muscular strength. Instead, gender becomes a way-of denoting "cultural constructions"- the entire social creation of ideas about appropriate roles for women and men. Gender is, in this definition, a social category imposed on a sexed body.

For Shularnith Firestone, reproduction was also the "bitter trap" for women. In her more materialistic analysis, however, liberation would come with transformations in reproduction technology, which might in some not too distant future, eliminate the need for women's bodies as the agents of species reproduction [6].

Some scholars, notably anthropologists have restricted the use of gender to the kinship system (focusing on household and family as the basis for social organization). We need a broader view that includes not only kinship but also (especially for complex modern societies) the labor market (a sex-segregated labor market is a part of the process of gender construction), education (all male, single-sex, or coeducational institutions are part of the same process), and the polity (universal male suffrage is part of the process of gender construction). It makes little sense to force these institutions back to functional utility in the kinship system, or to argue that contemporary relationships between men and women are artifacts of older kinship systems based on the exchange of women. Gender, is constructed through kinship, but not exclusively; it is constructed as well in the economy and the polity, which, in our society at least, now operates largely independently of kinship [6].

\section{Rural Spaces}

They are, the camera established, with ordinary laws of municipalities, what are the urban and rural space, and sanctioned by mayor. Urban, space, is defined by the municipality following the municipity's political and economic criteria.

Viewing just the aging process, from the point of view of chronological age, although it has been widely used, and almost exclusively in discussions about aging, may involve a real political struggle about what is at stake, the redefinition of the powers attached to different social groups at different points in the lifecycle.

So just to see the aging process from the perspective of ageclipping is a methodological error. Bourdieu [7] asserts the political sense of the danger of stratification of the ages in his sentence: "the age is a biological date socially manipulative and manipulable”.

\section{METHOD.}

\subsection{Participants}

Participated 27 women aged between 68 to 92 years. The elderly women in this study diverged into two major groups:

1) The individuals who were born in the region, which had lived and worked locally, all their lives, and were farmer wives or female farmers. Women own the land is $100 \%$ mostly white with blue or green eyes.

2) Who had lived and worked locally all their lives for farmers and their wives. Women spouses of employees or sharecroppers are black or brown and residing in the village.

Educational level: As for schooling, only one studied 5 years (farmer), but two thirds are illiterate and one third have functional literacy. Bible through five elderly learned to read.

The mathematical average of the number (10) children for woman (1). Birth rates, maternal mortality, infant mortality were present in almost all the speeches of women over seventy years.

Only four receive retirement as peasant, three owners of land and a former employee, the other to receive her husband's pension or are included in the Provision of Continued Benefit (PBC). It is noteworthy that the minority knows the distinction between retirement and PBC [8]. Benefits to Provide Continued article 20: are guaranteed for one (1) monthly minimum wage for the disabled and elderly with seventy (70) years or more and do not have to prove itself a means of providing maintenance and nor have it provided by his family. Article 20 $\S 3^{\circ}$ : It is unable to provide maintenance of the disabled or elderly family whose monthly income per capita is less than $1 / 4$ (one fourth) of the minimum wage. It is an 
individual benefit, it is not transferable, and it is not perennial [8].

The networks of social relations are present in this community. Marriage between relatives is very common among first cousins, second, third and fourth degree. The "godfathers" relations does establish between families: children, brother, aunts and grandparents. Old women's godfathers relations encompasses the degree of kinship, when instead refer to "My Sister X" they refer "my godmother X". In Brazil it is noteworthy that the god fathers relations is seen as a way of accessing the relations of reciprocity vertical and horizontal forming an important part of the ways by which circulating resources and structured hierarchies in societies [9-11].

In Greekpol is, the son could not be a citizen while his father was alive, when he died, only the eldest son enjoyed political rights [12], in the patriarchal family was the man who played the roles of procreation, economic management and political leadership. The unit family must be preserve at all costs, and there fore marriages were common among relatives. The fortune of the clan and its properties remained so in divisible under the leadership of patriarch [13].

Listening the life's history of these women, their behaviors in relation to the life cycle and their routine (childhood, adolescence, courtship, marriage, children, work, religion, leisure and others), and comparing them with that read my book collection I found some older as true protagonists of some literary works.

A Hundred percent (100\%) of women declare themselves Catholic.

I watched the very low age of grids and the events marked by them as a line of almost sequential life. I could see traces of paradigms and review of antiquity that still persist in unchanging and endless repetition and perennial naturalized inequalities and sexual division of labor in both production processes of reproduction of these women.

\subsection{Lócus}

This district has a history of agrarian tradition with large coffee plantations, a product that, although less so, still today constitutes a source of income and seasonal employment for men and women of the locality. Its population amounts to 1014 people. The rural area has 590 inhabitants. The population amounts to 1014 inhabitants, in space urban lives 424 people. The rural area has 590 inhabitants.

There is not institution or affiliation linked to themes of active citizenship in this district. The secondary education, it has been implemented, only four years ago.

The catholic religion is predominant. Was recently installed an evangelical church "Assembly of God", that principle has created some conflict in socializing among people of rural and urban space. In the urban area has two streets, but for residents of the district the town is known as street. The existing trades are two small bars and as mall store, where they sell a few products. For make the purchase of the month, they have to go to the "street" (town).

In the narrative, the railway is a landmark delimiter, and synonymous with opulence and wealth of the district. Rather, its extinction indicates misery and emptying, what did find in several passages like the following:

All existed there, the cloth trade, pharmacy, butchers, bakers, a pries reside there. There was much progress. Near the station had a wonderful plantation, where he lived Mr. Charles and owner Anita, Manuel Vieira, who owned the coffee roasting factory, Mr. Sebastian Vieira, and they were abandoning their houses. When the train line was extinguished, the district was ending, was failing (I have 92 years, here I will go to 93, I was born here, I grew up here, and I am here, today).

The distances (large or small), both between farms and the core of the neighborhood, and among the people, make it difficult to understand who do not live there, the elements that congregate: crony ties, kinship ties, religious ties and friendships.

Spite of observing the social and economic stratification between those women interviewed, I chose to reinterpret their narratives not the category "class", but the sense of belonging to the locality, whose formation depends, it is not only on geographic location and social, plus also the exchange between the families and the people who share the same territory of cultural meanings.

\section{FINDINGS}

Within innumerable findings, this article will discuss the violation of pension rights, the rural elderly woman. Retirement as a landmark, economic and chronological, aging is not homogeneous in our country. The World Health Organization (WHO) has created a cutting age to treat aging, which refers to the population over 65 years of age in developed countries and with over 60 years of age in developing countries [14].

In Brazil urban workers can request retirement, male from the 65 years old and females from the 60 and Rural workers may request retirement at age 60 for men and 55 years old for women [15].

The age cut for purposes of retirement and demarcation of aging in Brazil works according to capitalist logic (sometimes as sixty and sixty-five years old, sometimes as 65 and 70 years old) that depends on the social political it will be inserted. This cut is less than five years for the rural population, i.e. fifty-five or sixty years for rural women, but all women research retired or receiving government benefit over 65 years, many were still awaiting 
court decision.

Official recognition as "agricultural workers" to achieve retirement has always been difficult to prove, given that much of the work done by these women is what Arendt [12] called labor:

Something invisible that vanishes as soon as it "was done", and must always be resumed, often stated as "help" to the task of man, even when linked to production, such as the harvest, the transport of production, weeding, planting, creation and others, as befits the patriarchal regime.

It is very difficult for a woman "from the fields" have to submit documentary evidence to attest to the years worked, among which, the Registry of Property (INCRA), in the Lease Agreement (sharecropper, partner and others), Notepad sale of production, the statement of the union rural, and the testimonial evidence, among others. Most of these documents rarely issued to spouses of women have hindered their access to rural retirement. It is true that this is also happening with less educated workers, the laborers who work day, with day laborers and those who do work per task. Moreover, these difficulties eventually create a segment profiteers themselves as rural unions and lawyers to require a right enshrined in the Constitution $[15,16]$.

Examples are many:

"Now I have, just recently I started receiving" (78 years old).

"Now I have it, it does a while ago" (92 years old).

(...) "With great difficulty succeeded, I had to hire a lawyer" (72 years old).

"I request retirement, but never came out. Put in the hands of a lawyer today ... did not. Already four years, and he says come yet. You believe that" (92 years old).

In addition to the documents, also, they are valuated by their physical appearance. The physical presentation of himself seems to hold for the socially and morally. The appearance of action places the actor under the appreciative gaze of the other, and especially in the context of prejudice fixing in advance a social category or moral, as the aspect or detail of the piece, as the shape of the body or face. Stereotypes are fixed in physical appearance and become stigmata, or marks on the moral imperfection fatal, or belonging [17].

G. S. He said-Mary broth burning sun there [before attending the expertise of the INSS] (77 years old). To which the woman replied:

"Oh! Gerald not talks to me like there. Oh my God. So much that I am burning to work under the sun. My hands are calloused from both weeding, planting vegetable, sweeping the yard" (68 years old).

\section{THEORETICAL FRAMEWORK}

Seeking answers to these questions, we set theory by
Arendt and official documents.

Following the route of the model of the Greek polis, in the book "The Human Condition", Arendt [12] designates three fundamental human activities of the human condition: action, work and labor.

\subsection{The Action}

In Greek polis, free men in the public sphere performed the action. The term "public" signifies two closely interrelated but not altogether identical phenomena: It means, first, that everything that appears in public, it can be see, and heard by everybody and has the widest possible publicity. For us, appearance-something that is being seen and heard by others as well, as by ourselves-constitutes reality [12].

Second, the term "public" signifies the world itself, as far as it is common to all of us and distinguished from our privately owned place in it. This world, however, is not identical with the earth or with nature, as the limited space for the movement of men and the general condition of organic life. It was relate, rather, to the human artifact, the fabrication of human hands, as well as to affairs, which go on among those who inhabit the man-made world together [12].

It is the publicity of the public realm, which can absorb and make shine through the centuries whatever men may want to save from the natural ruin of time. Through many ages before us - but now not any more-, men entered the public realm because they wanted something of their own or something they had in common with others to be more permanent than their earthly lives (Thus, the curse of slavery consisted not only in being deprive of freedom and of visibility, but also in the fear of these obscure people themselves "that from being obscure they should pass away leaving no trace that they have existed") (12).

Action is the political activity par excellence. The political being, living in a polis, meant that everything was decided through words and persuasion, not by force or violence. During this period, the public space was preserve to free men, men of action, speech, the construction of knowledge.

\subsection{Labor}

The labor was carried out in the private sphere. If everything in the public sphere was determined through words and persuasion, not by force or violence, family life, the head of the house ruled with unquestionable power and despotic. Forcing someone through violence, order rather than persuade, were pre-political ways of dealing with people, typical of life outside the polis, characteristics of the home and family life. In the private sphere lived slaves, women and peasants, not as real hu- 
man beings, but only the "specimen of human animals". Resided there, precisely, the ultimate reason the vast contempt with which the ancients regarded. Beings who live in the private sphere do not get to know, and therefore is deemed not to exist [12]. According to Aristotle, it would be possible to offer citizenship to the painters and pastors, but not the peasants. Such differences can be explained because the labor rests on the conviction that it is exercised and required in order to meet the basic needs of life, so the peasants who produce to maintain livelihoods and life should be considered slaves. The two qualities that, according to Aristotle, the slave does not have-and it is because of these defects he is not human - is the ability to deliberate and decide, and predict and choose. Kept out of sight were the workers who, with his body, took care of the needs (physical) life, and women with your body, ensure the physical survival of the species. Women and slaves belonged to the same category and were kept out of sight of others-not only because it was the property of another, however because his life was "laborious", devoted to bodily functions.

The work is typical for homo Faber, its activity corresponds to the artificiality of the human existence. The work produces an artificial world clearly distinct from any natural environment. The human condition of work is worldliness. The work and your product-the human artifact-lend some permanence and durability to the futility of mortal life and the ephemeral character of human time. It is only at the end of the fifth century BC that began classifying occupations according to the amount of time and effort required. For before, especially in the Greek world, the whole primacy did give to politics [12].

If in ancient Greece, they were performing activities of labor that produced to maintain livelihoods and life should be consider, and the peasants would be denied their citizenship, even change their status. In a not so distant past, in Brazil, the history of citizenship of peasants did not differ much from the Greek polis.

\section{RURAL ELDERLY WOMEN: RIGHTS AND CITIZENSHIP}

The Brazil's rights history of well-being and inclusion of rural workers in Brazil as a subject, he was and still is much debated in academia, this article will be presented an overview of some studies [15-23].

Although the Constitution of 1934 decreed that all Brazilians should have rights to social security protection, the Constitution did not include farm workers, although the rural population constituted the majority at that time, and thus it was until the 1960's.

In Brazil in 1943 is enacted works laws, where only members are citizens of the community that is located in any activity of the occupations defined and regulated by laws. Santos [18] defines as regulated citizenship—which its roots are not in civil codes, but in an occupational stratification, which is define as a legal norm. The regulation of professions, the professional portfolio, and define public union, so the three parameters within which end up defining citizenship. The legal instrument proof of contract between the state and regulated citizenship is the portfolio of work that becomes more evidence work, a birth certificate Civic. Once more farm workers were excluded.

Government social policies of the 1930s, 1940s and 1950s were included almost all urban workers and the majority of self-employed among the occupational groups with the right coverage. The exception was the rural workers, domestic workers and self-employed professionals [18-23].

The first attempt to include farm workers in the social security system, it was the Rural Worker, created by Law 4.214 (03/02/1963), but it was not regulated.

Only after the creation of the assistance plan for rural workers (PRORURAL), Law 69919 enacted in 1972, it is that the country's government predicts disability retirement benefits, funeral assistance and health care and social service workers (women) in the field.

In hers reports, we observed that the absence of title to land generated Tying the father, husband or brother.

Only one family member had a right to access the PRORURAL. So this was a right of the "head of household”, usually the man. To rural women workers was guarantee only as dependents, which gave them the right to a pension, upon the death of her husband farm worker.

If the inclusion of the rural man was late compared to other professions, women were only included in the 1988 Constitution, In its articles 200, 203 Section V, where rural women workers became eligible for retirement by age, after 55 years, regardless of the spouse already be beneficial or not, or receive pension for the spouse [16].

\section{CONCLUSIONS}

In this study, I could see, hear and observe; it was the paradox between the effectiveness of laws, programs and policies-juridical and institutional objectivity, to eliminate discrimination against women that lasted for centuries. Progress and struggles against inequality and empowerment of rural elderly women, still live with images which seemingly are immune to the persistence of the values of the Greek polis. The perpetration of the paradigms of the Greek polis, now coated in new words such as exclusion, inequality, prejudice, patriarchy, symbolic violence against rural women in their aging process, is veiled and revealed in the narratives of these elderly.

The literature on the study of retirement and aging has appointed these phenomena as stages of sadness, loneliness and abandonment [24-28]. However, there are authors who speak of the joy and empowerment of older 
people, especially many older women. For these women, retirement is an enjoyment, many for the first time, to receive a cash benefit that is only yours and you can share it with their families. The retirement as a resource for not living in penury is a right and a necessity in this period of life.

As Deleuze points out-what is terrible in old age? It is the pain and the misery. However, the problem is not old age itself. What is pathetic, and makes a sad old age, are poor people who cannot afford to live, or a minimum of necessary health and suffering for it. That is what is terrible, and it is not old age! Old age is not an evil in itself [29].

The receipt of the benefit, and no retirement for these older, corresponding to violation of their civil rights and non-recognition of their work in the fields and at home, aren't tied to the meaning of the work performed, the benefit corresponding to the right acquired by age, as "helper work" in the field, when young women, now as older women receive a government support. In their life's history, they have always been seen as helper working in the field, as the protagonist never, never as citizens with rights entitled.

Returning to the concepts of the Greek polis as a: "public sphere (man/action), private sphere (slave/labor), work (permanency)”, where women and slaves belonged to the same category and were kept out of sight of others-not only because it was owned by someone, but also because his life was "laborious”, dedicated to bodily functions.

The view of public managers, for the rural elderly women, remains anchored in the Greek polis, where work of their hands and the sweat of their faces, does not mean work; it is labor.

\section{ACKNOWLEDGEMENTS}

I would like to thank the support of a grant from the CAPS (Center for the Improvement of Higher Education) and older women to fill the skeleton topographic community signs and meanings.

\section{REFERENCES}

[1] Brazilian Institute of Geography and Statistics (2010) Synthesis of Social Indicators Census. http://www.senso2010.ibge.gov.br.Censo

[2] Brazilian Institute of Geography and Statistics (1991) Synopsis of the Census: Operational base.

[3] Beauvoir, S. (1967) The Second Sex. European broadcast Books.

[4] Chauí, M. (2000) Invitation to philosophy. Ática, Rio de Janeiro.

[5] Schroots, J.J.F. and Birren, J.E. (1990) Concepts of time and aging in science. In: Birren, J.E. and Warner Schaie, K., Eds., The handbook of psychology of aging, Academic
Press, San Diego, 24-31. http://dx.doi.org/10.1016/B978-0-12-101280-9.50009-7

[6] Scott, W.J. (1986) Gender: A useful category of historical analysis. The American Historical Review, 91, 1053-1075

[7] Bourdieu, P. (1984) Sociology in questiones. Bertrand, Rio de Janeiro.

[8] Organic Law of Social Assistance (1993) Law No 8.742, Section I-The Benefit of Continued Service. Article 20.

[9] Freire, G (2003) The masters and the slaves: A study in the development of Brazilian civilization. Global, São Paulo.

[10] Brügger, S.M.J. (2002) Patriarchal Minas: Family and society (São João del Rei, 18th and 19th centuries). Doctoral Thesis, UFF, Niteroi, 5.

[11] Farinatti, L.A. (2012) The sword and the chapel: Relationships of godfathers among militia officers in the southern borderland of Brazil (1816-1835). History Unisinos, 16, 294-306. http://dx.doi.org/10.4013/htu.2012.163.03

[12] Arendt, H. (1958) The human condition. The University of Chicago Press, Ltd., London.

[13] Freire, G. (1981) Master \& Slaves: Formation of the Brazilian family under the regime of patriarchal economy. 21st Edition, José Olympio, Rio de Janeiro.

[14] World Health Organization (1984) The uses of epidemiology in the study of the elderly. WHO, Geneva.

[15] Ministry of Social Security-Retirement age.

[16] Constitution of the Federative Republic of Brazil (1988) Article 202I.

[17] Goffman, E. (1963) Stigma: Notes on the management of spoiled identity.

[18] dos Santos, W.G. (1993) Reasons disorders. Rocco, Rio de Janeiro.

[19] Barros, M.R.L. (2003) Testimony of life: An anthropological study of women in old age. In: Old age or old age? Anthropological studies on identity, memory and politics, FGV, Rio de Janeiro, 113-165.

[20] Delgado, G. Jr. and Cardoso, J.C. (2000). The universalization of social rights in Brazil: Rural Welfare in the 90s. IPEA, Brasília.

[21] Brumer, A. (2002) Rural Social Welfare and gender. Previdência. Sociologias, 7, 50. http://dx.doi.org/10.1590/S1517-45222002000100003

[22] Schwarzer, H. (2000) Socioeconomic impacts of the pension system in rural Brazil-Empirical evidence from a case study in the state of Pará. IPEA, Rio de Janeiro, Textfor Discussion No. 729.

[23] Schaaf, A.V.D. (2003) The rural woman's way: The struggle for social rights and gender equality in Rio Grande do Sul. Sociology, 5, 412-442. http://dx.doi.org/10.1590/S1517-45222003000200014

[24] França, L.H.F.P. and Vaughan, G. (2008) Gains and losses: Attitudes of Brazilian and New Zealand executives towards retirement. Psicologia em Estudo, 13, 207-216. http://dx.doi.org/10.1590/S1413-73722008000200002

[25] Moreira, J.O. (2011) Work, retirement, old age: A case study with university professors. Psicologia em Estudo, 
16, 541-550.

http://dx.doi.org/10.1590/S1413-73722011000400005

[26] Souza, R.F., Matias, H.A. and Brêtas, A.C.P. (2010) Reflexions about aging and work. Ciência \& Saúde Coletiva, 15, 2835-2843.

http://dx.doi.org/10.1590/S1413-81232010000600021

[27] Canizares, J.C.L. and Jacob, F. (2011) Senility risk factors upon retirement transition. Revista Brasileira de Geriatria e Gerontologia, 14, 425-432.

[28] Siqueira, S.A.V. (2006) The rural security and the benefit of installment continued in the social protection to the Brazilian elderly: An analysis of the institutional changes in the decade of 1990. Theses, Foundation Oswald Cruz (Fiocruz), Rio de Janeiro.

[29] Deleuze, G.M. (1989) de Maladie. The ABCs of Gilles Deleuze.

http://www.oestrangeiro.net/esquizoanalise/67-o-abecedar io-de-gilles-deleuze 